\title{
DESIGNING NOTE SHARING APPLICATION ON ANDROID PLATFORM
}

\author{
Renan Prasta Jenie; Karyana Hutomo; Freddy Wijaya \\ Computer Science Department, School of Computer Science Binus University \\ Jl. K.H. Syahdan No. 9, Palmerah, Jakarta Barat 11480 \\ rjenie@binus.ac.id
}

\begin{abstract}
Writing notes on paper is fun because we can simply write whatever we want on it. Writing notes in the digital media is also advantageous for it can be shared directly. If we can combine the two functions, it will be more profitable. Therefore, the author wants to combine the benefits of writing as you wish like as on paper with contemporary digital writing. Somehow, writing using PC cannot be done at any time due to the needs of both electrical connection and space availabilty. Therefore, Smartphone or tablet is the right choice because it is not tied to two needs. The Smartphone to be selected is the one built with android platform for ease of note transfer compared to other platforms.
\end{abstract}

Keywords: writing, note transfer, digital, smartphone, Android

\begin{abstract}
ABSTRAK
Menulis catatan di media kertas memang menyenangkan karena kita dapat dengan mudah menuangkan apapun yang ingin kita tulis. Menulis catatan di media digital juga menguntungkan, satunya dapat dibagi-pakai secara langsung. Jika kita bisa menggabungkan dua fungsi tersebut tentunya akan lebih menguntungkan. Oleh karena itu, penulis ingin menggabungkan manfaat menulis sesuai keinginan seperti menulis di atas kertas dengan menulis di media digital. Menulis di media PC tidak bisa dilakukan setiap saat terkait dengan kebutuhan sambungan listrik dan tempat yang memadai. Oleh sebab itu, smartphone atau tablet adalah pilihan yang tepat karena tidak terikat dua kebutuhan tersebut. Smartphone yang akan dipilih yaitu yang berplatform android untuk kemudahan penyebaran dibandingkan platform lainnya.
\end{abstract}

Kata kunci: menulis, transfer catatan, digital, smartphone, Android 


\section{INTRODUCTION}

Smartphone is not only a device that lets you make telephone calls, but also adds features that you might find on a personal digital assistant or a computer. A smartphone offers the ability to send and receive e-mails and edit Office documents, for example. While there is no standard definition of the term "Smartphone" across the industry, there are a few features that you will find on every Smartphone. Smartphone is based on an operating system that allows it to run productivity applications, such as the BlackBerry OS, the Palm OS, or Windows Mobile Software. Smartphone offers more than just an address book. It may allow you to create and edit Microsoft Office documents or manage your finances. Smartphone also offer some sort of access to the Internet. You can use your Smartphone to browse your favourite websites. It is also able to send and receive e-mail. Even some smartphones can support multiple e-mail accounts. Others include accesses to the popular instant messaging services, like AOL's AIM and Yahoo! Messenger. Smartphone is usually built with QWERTY keyboard, so the keys are laid out in the same way they are on your computer keyboard.

Wallet-sized Smartphone can be used to write even keep such records. However, writing notes on Smartphone or pad has limitations because the keypad provide only standard the type of letters and symbols. It will be nice if we write anything without character limitation as we write on paper, but it can be stored and easy to be seen again on the Smartphone or media pad.

On another situation, when attending a seminar or meeting, sometimes we can only catch a little of what was delivered. When we're busy writing a note sometimes we miss the explanation is being discussed. In the short period, we may only write the outline of distributed materials that is difficult to make clear understandings about what was discussed. We need something to solve a problem like this. If notes can be written directly in a device, viewed simultaneously, and shared to other devices, of course it can make notes used more properly.

Therefore, through this research, a design is made for Smartphone note sharing. Androidplatform phone is used for case study.

\section{METHOD}

All cell phones can send and receive text messages, but what sets a Smartphone apart is its design. All design made uses Pressman standard. The notation made using UML 2.0. It is assumed that the process model used is Waterfall (Pressman, 2010). Some design components are omitted for simplicity.

\section{RESULTS AND DISCUSSION}

\section{Scenario Design}

The scenario made focuses on designing system with minimal number of views possible, such as in Figure 1. 


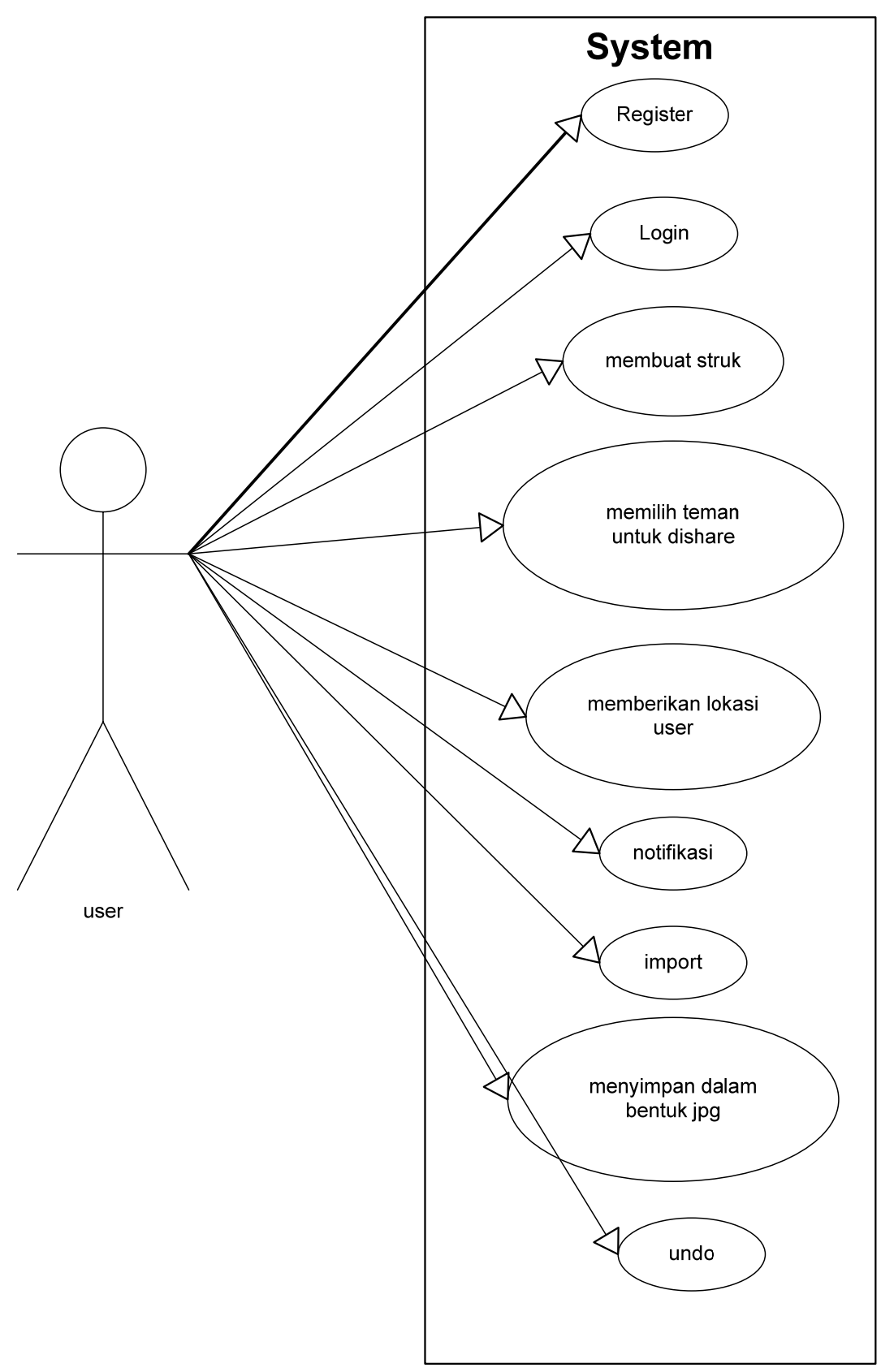

Figure 1. Use case diagram.

\section{Flow Design}

The data flow is designed to emphasize communication among the background designs (Figure 2). 


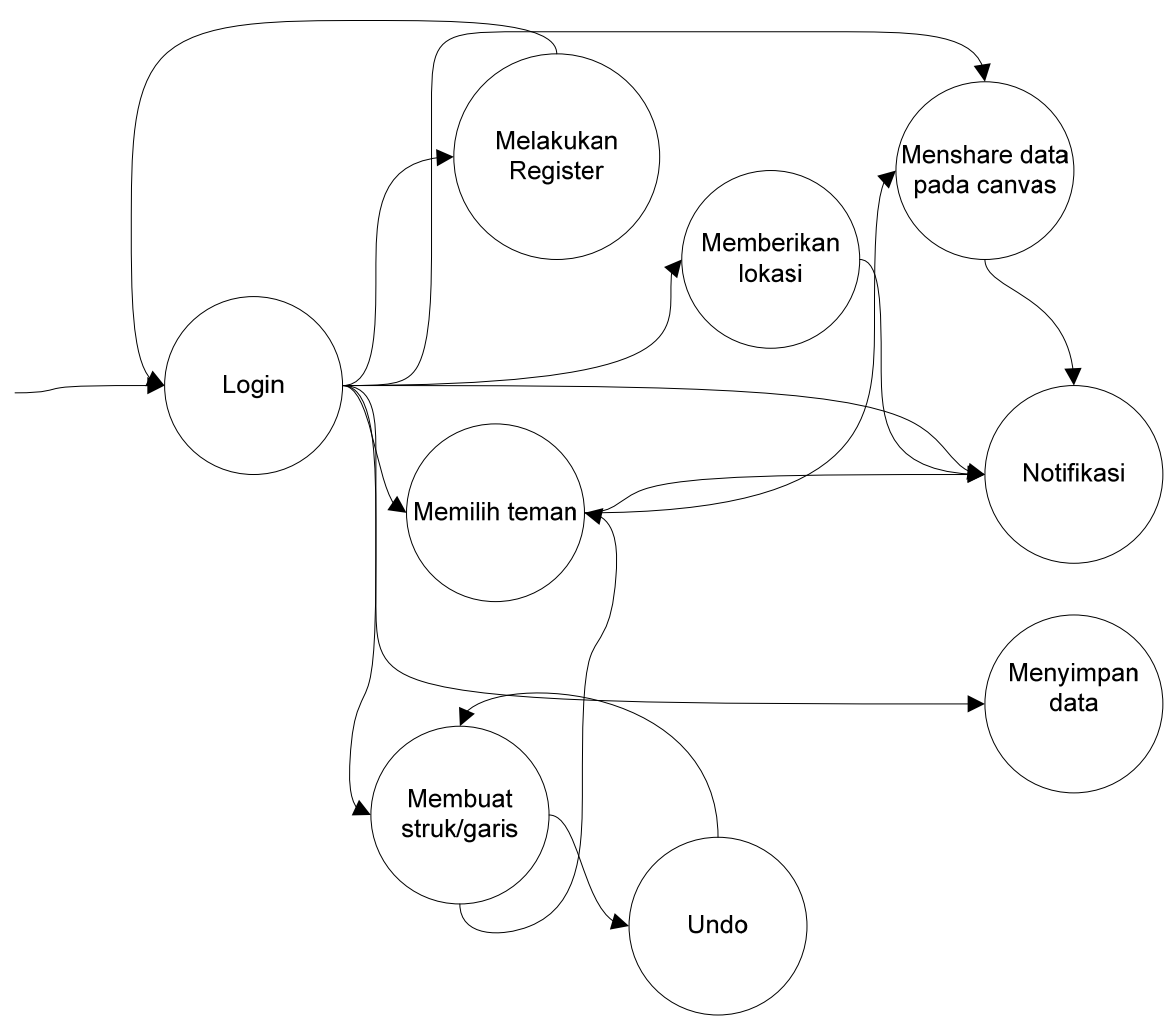

Figure 2. Data flow diagram.

\section{Class Design}

The system developed uses Model View Controller architecture (Figure 3).

\section{Behaviour Design}

Most of the system behaviour handled asynchronously, using controller class as the bot for execution, such as the example (Error! Reference source not found., Figure 5, Figure 6, Figure 7, Figure 8, Figure 9, and Figure 10). 


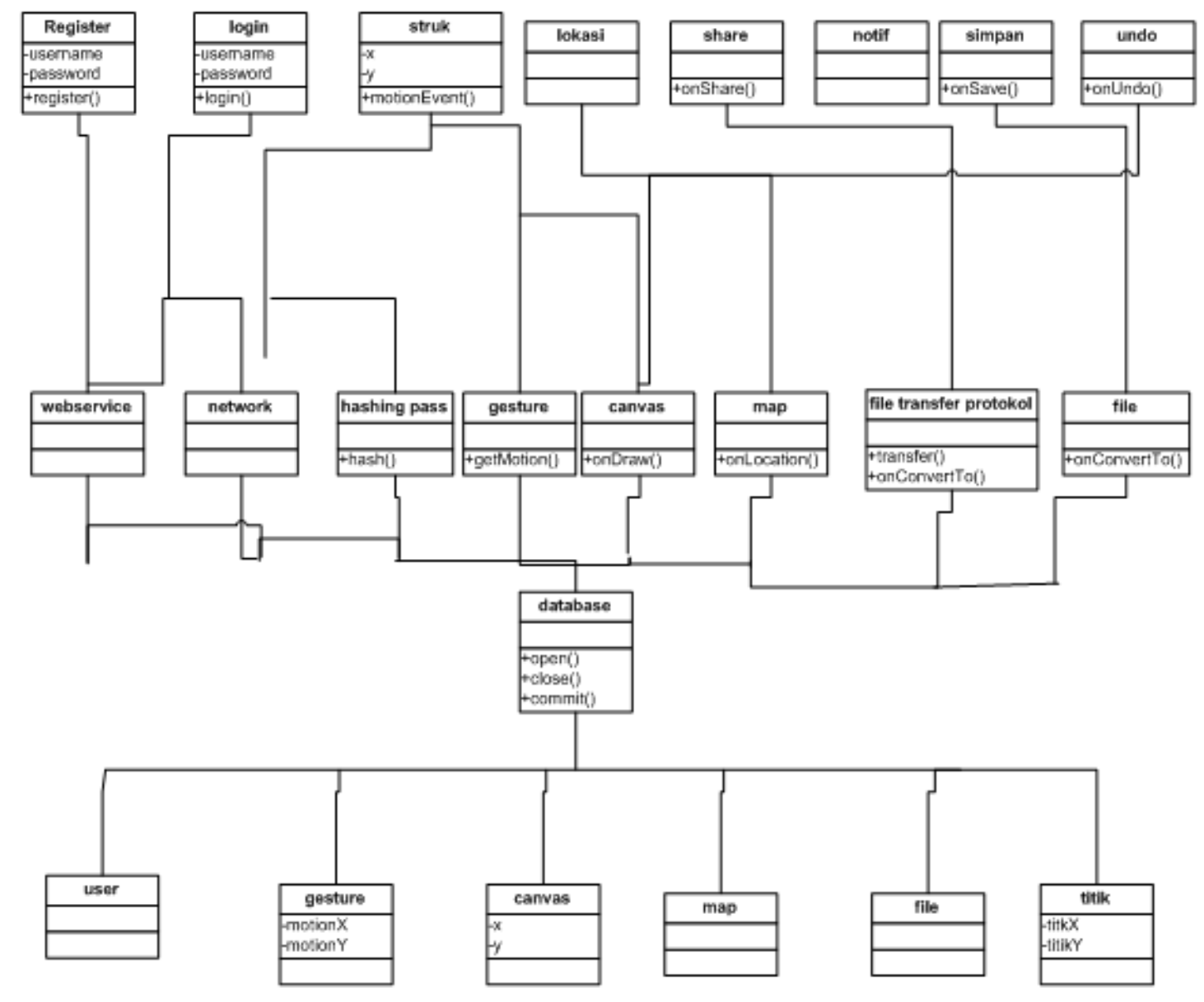

Figure 3. Class Diagram.

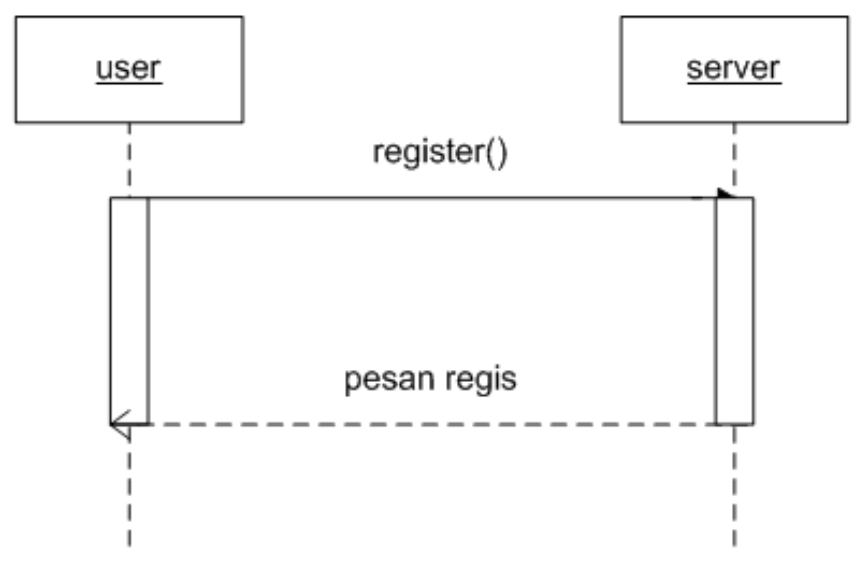

Figure 4. Sequence diagram - register. 


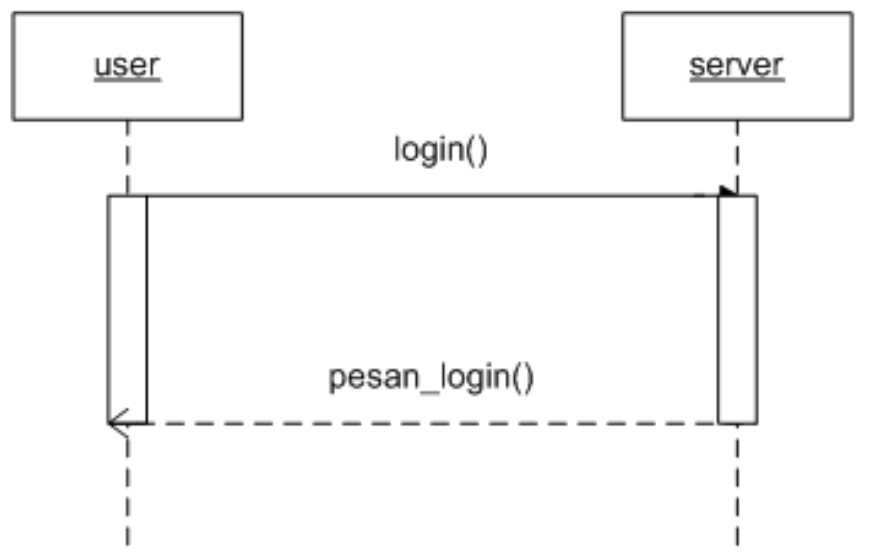

Figure 5. Sequence diagram - login.

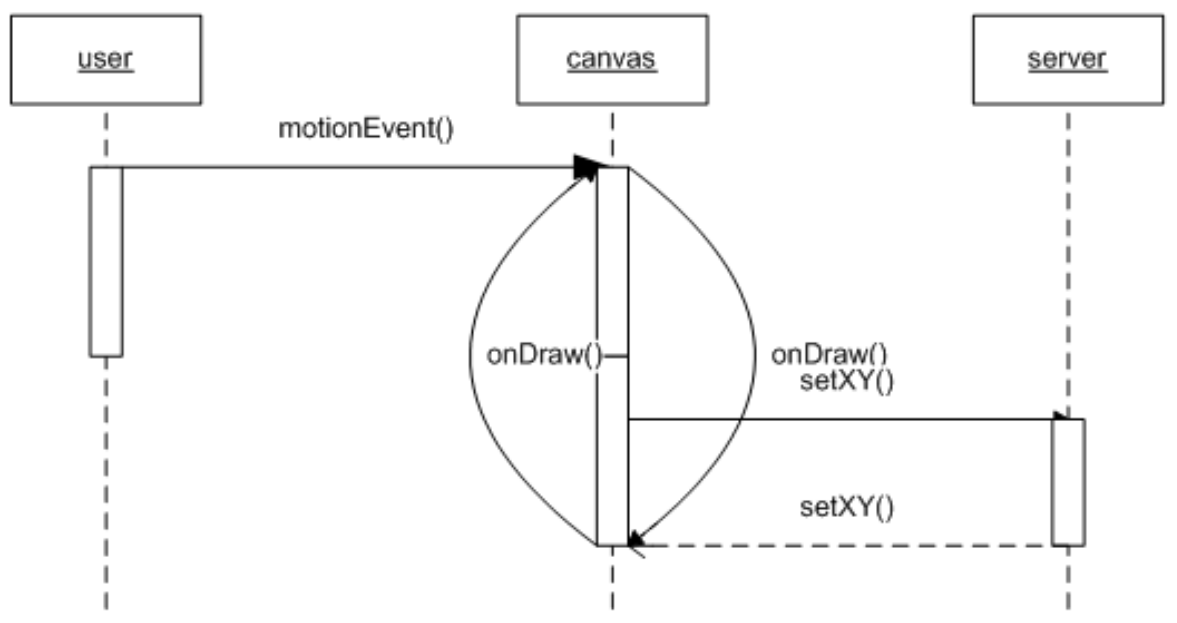

Figure 6. Sequence diagram - Create stroke.

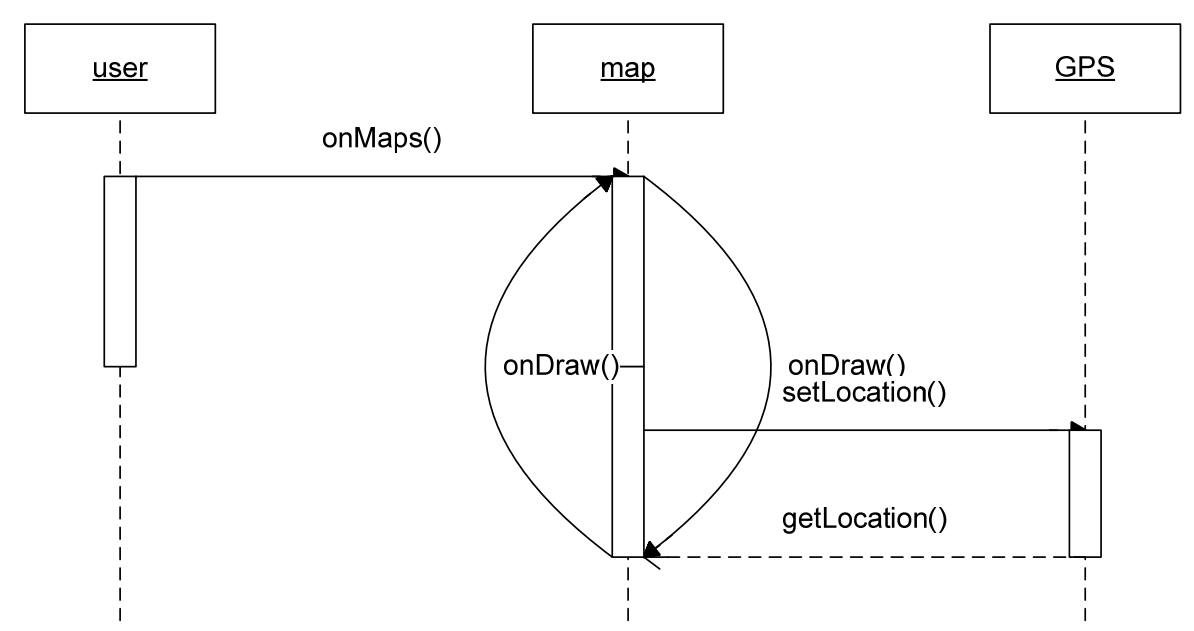

Figure 7. Sequence diagram - user location. 


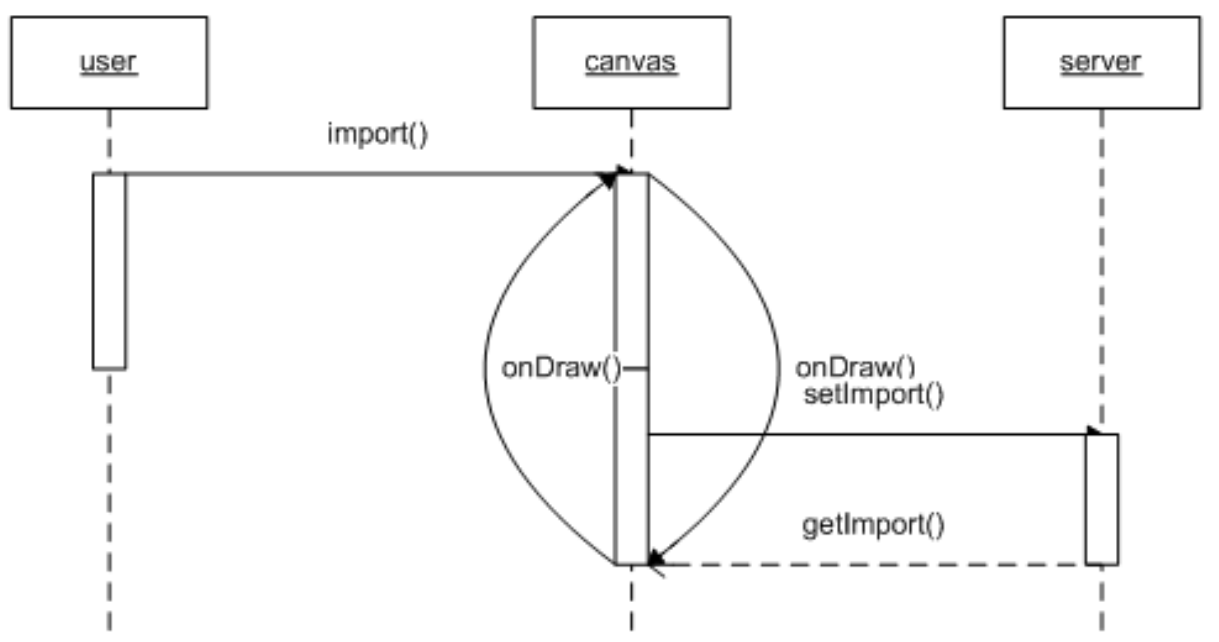

Figure 8. Sequence diagram - import canvas.

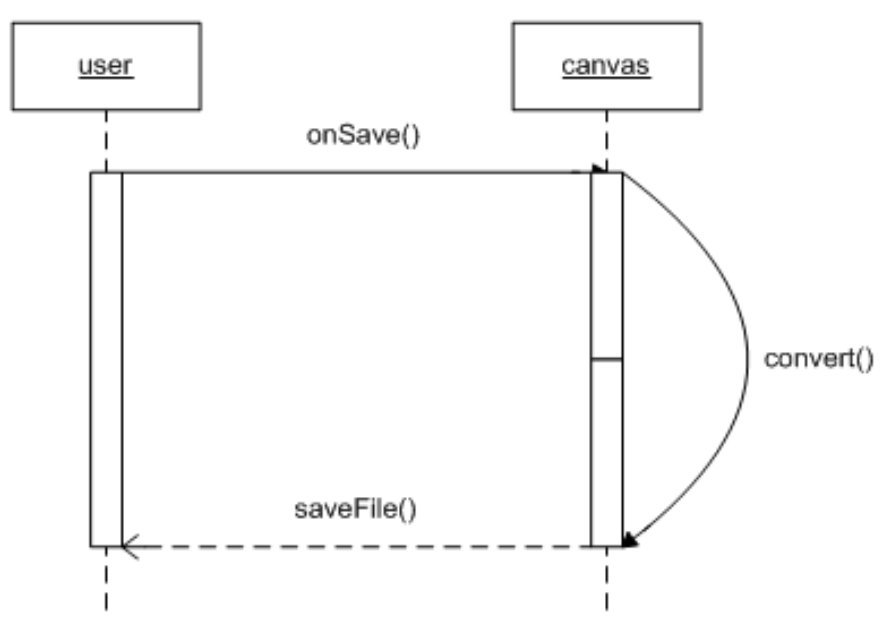

Figure 9. Sequence diagram - save file. 


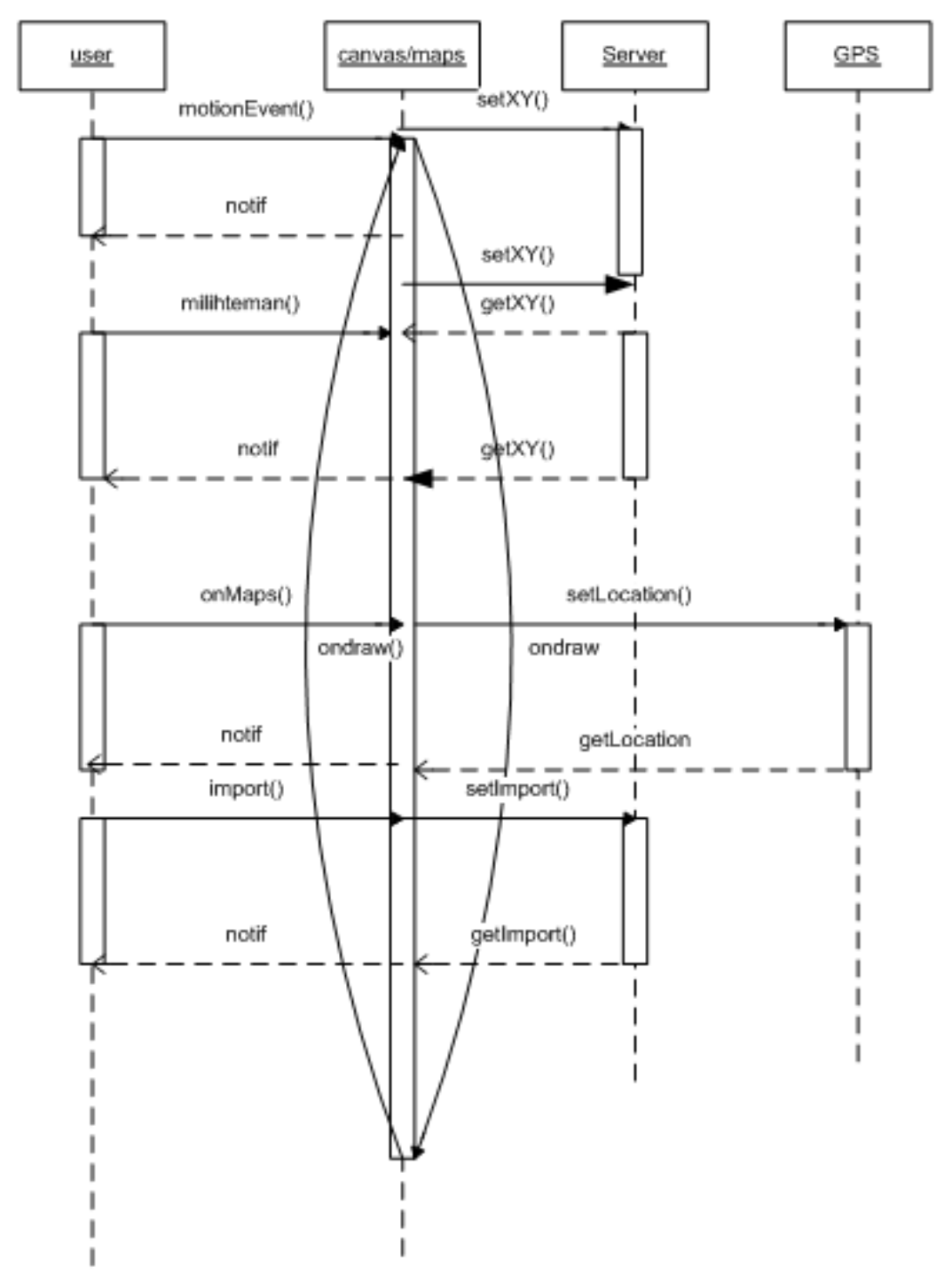

Figure 10. Sequence diagram - notification.

\section{Interface Design}

The interface design is built in regards of the capabilities of Android 3.0 (Google Inc., 2011). The design is tested using droid draw (DroidDraw Beta, 2011) (Figure 11, Figure 12, Figure 13, Figure 14, Figure 15, and Figure 16). 


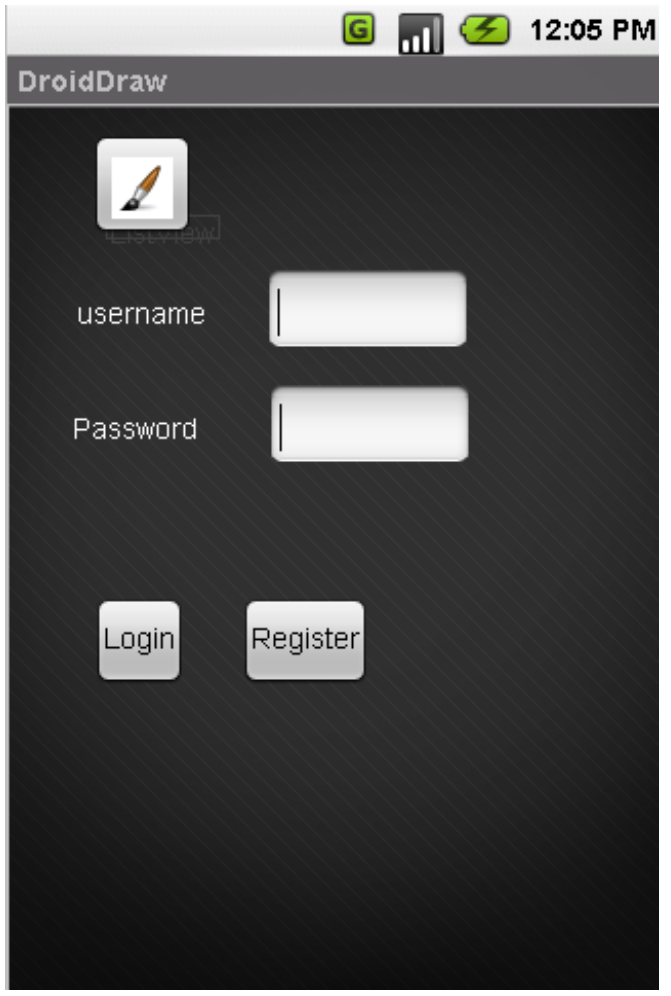

Figure 11. Interface design - login.

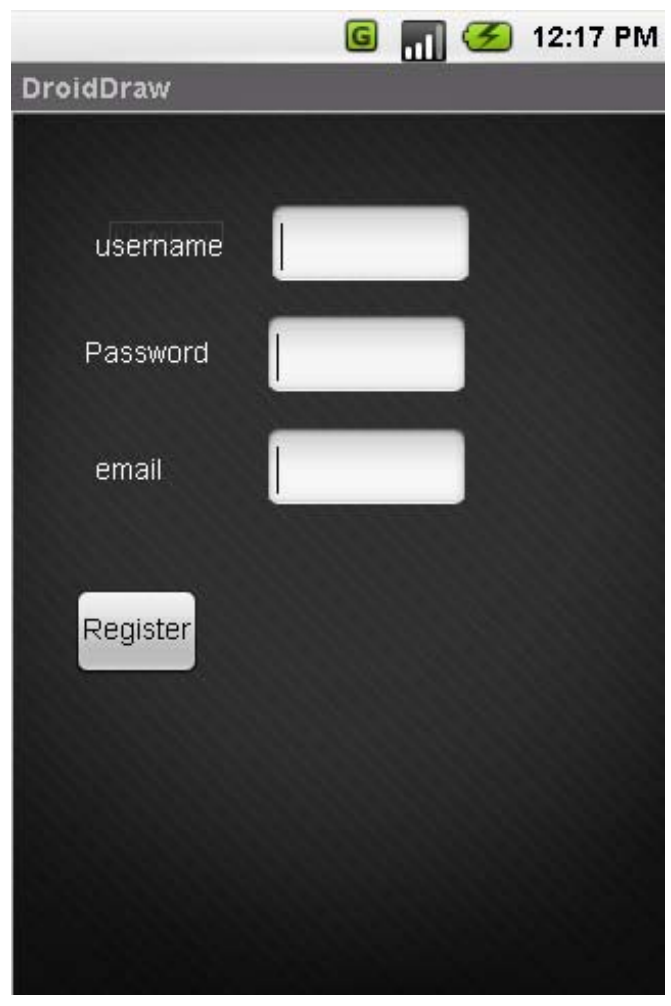

Figure 12. Interface design - register. 


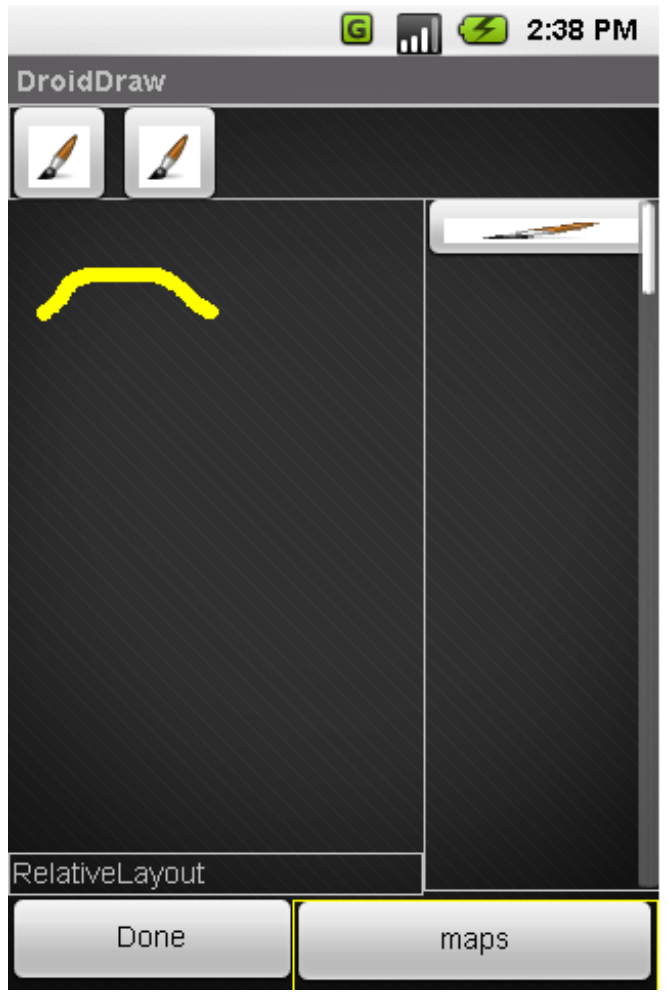

Figure 13. Interface design - main view.

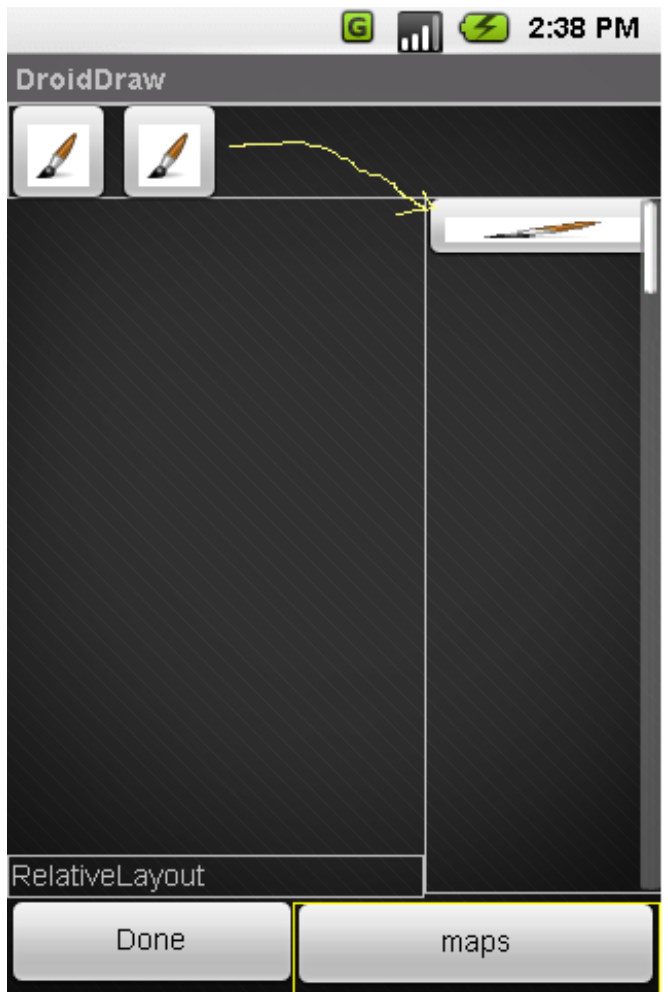

Figure 14. Interface design - pick friends in main view. 


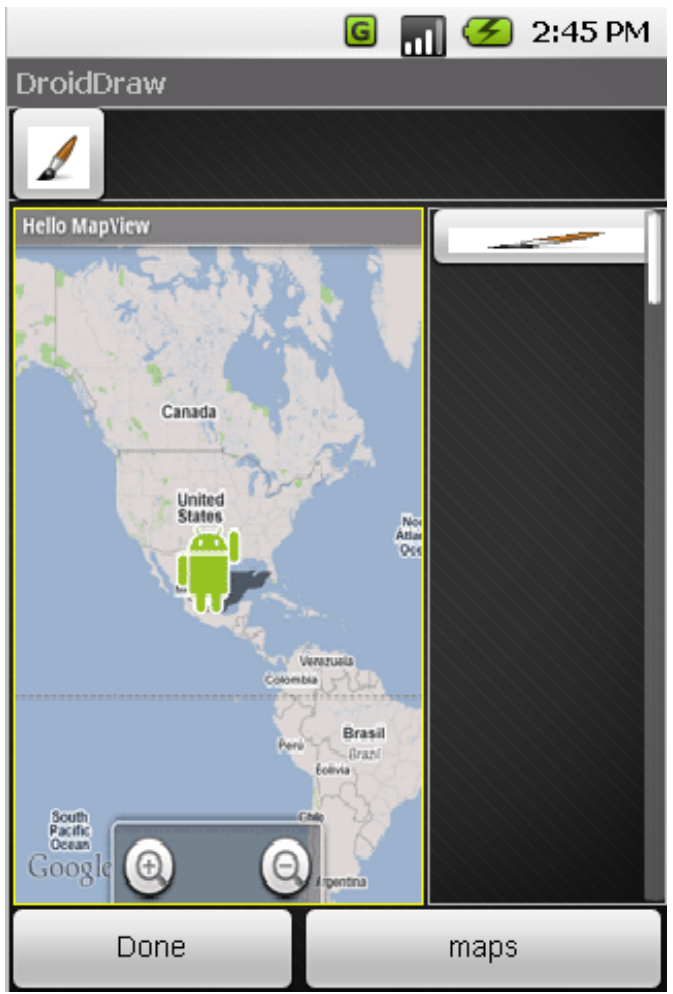

Figure 15. Interface design - map view.

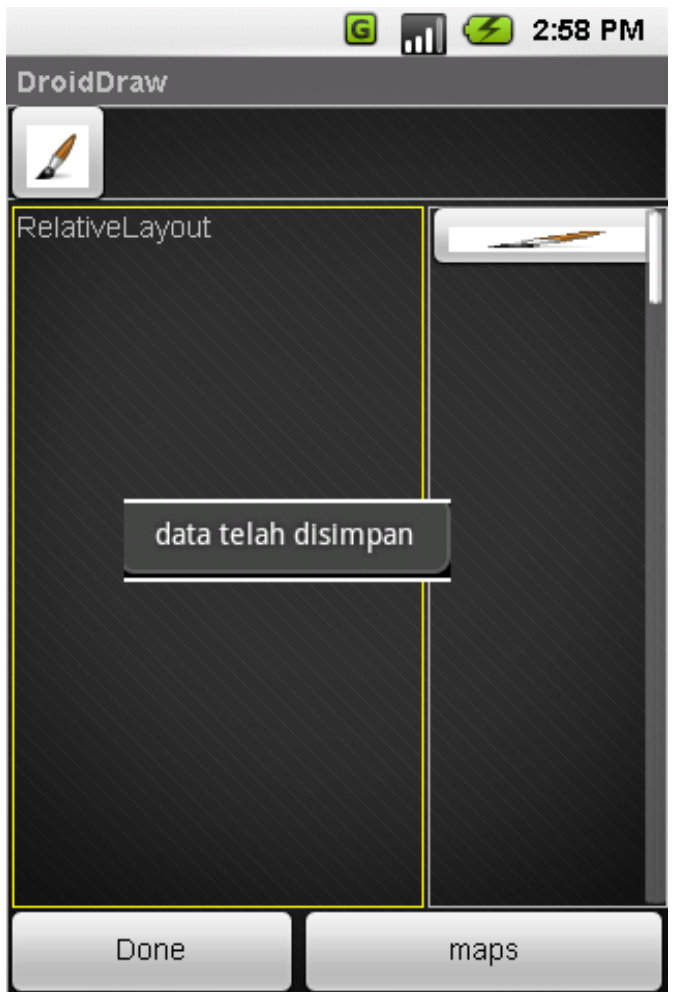

Figure 16. Interface design - save view. 


\section{Data Design}

The data is designed to catch the entire possible dot made between strokes. The communication built uses threads. The data designed for extendibility, so all the transaction can be done to a lot of connection. Here is the entity relationship diagram (Figure 17).

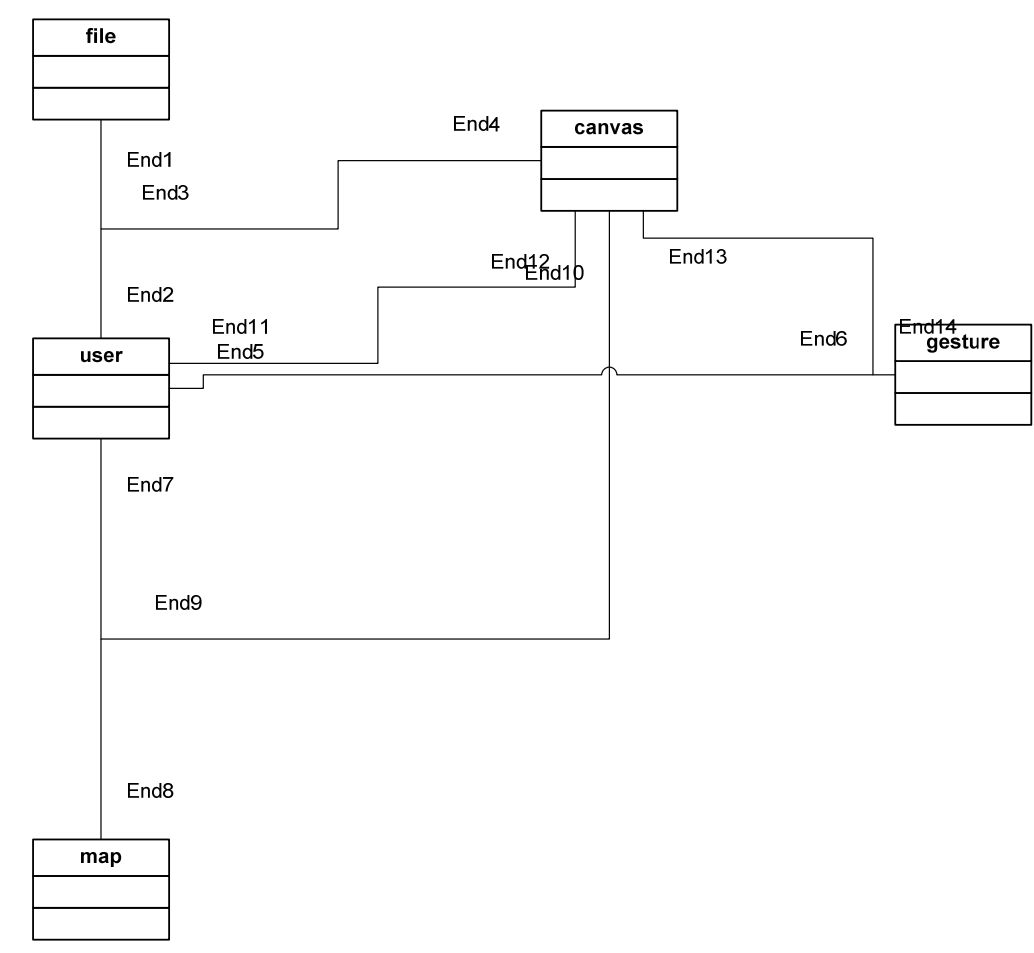

Figure 17. Entity relationship diagram.

\section{Architecture Design}

The whole system is developed using data centric architecture (Figure 18).

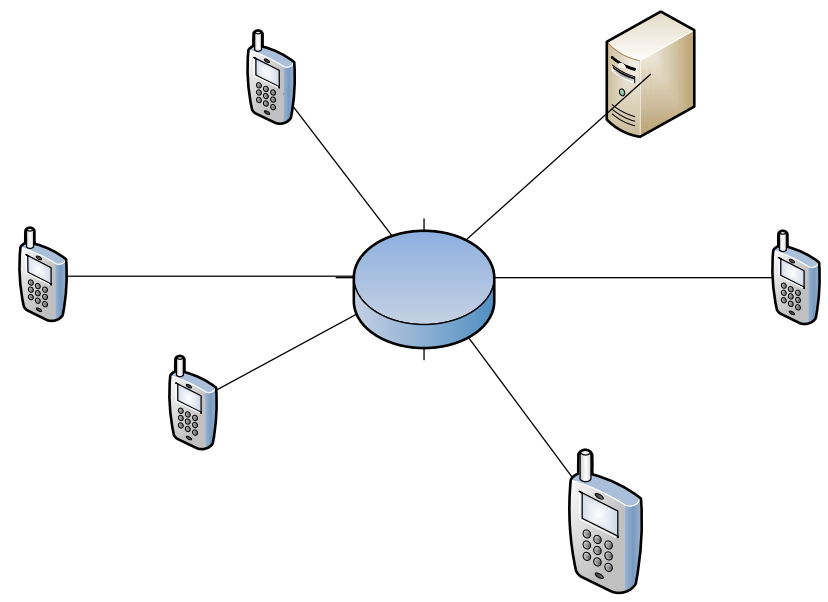

Figure 18. Architecture design. 


\section{CONCLUSION}

From the application design phases built, we can conclude that lines, file insertion and maps can enhanced the notes written on Smartphone and can be shared in real time.

\section{REFERENCE}

DroidDraw Beta. (2011). DroidDraw Beta. Retrieved February 19, 2011, from http://www.droiddraw.org/

Google. (2011). User Interface. Retrieved February 20, 2011, from http://developer.android.com/guide/topics/ui/index.html

Pressman, R. S. (2010). Software Engineering: A Practitioner's Approach, ( $7^{\text {th }}$ ed.). New York: McGraw-Hill. 